\title{
Assessing Endothelial Function in Normotensive Overweight Adolescent Using Dundee Step Test
}

\author{
Nawanto A. Prastowo, Rika Haryono, Peggy Lucida, Stella K. Indra \\ Department of Physiology, School of Medicine, University of Atmajaya, Jakarta, Indonesia
}

\begin{abstract}
Abstrak
Tujuan Remaja pria berat badan lebih (BBL) dengan tekanan darah normal mungkin memiliki gangguan fungsi endotel yang tidak terdeteksi dengan pemeriksaan rutin biasa. Penelitian ini bertujuan untuk mendeteksi gangguan fungsi endotel pada remaja BBL dengan tekanan darah normal menggunakan Dundee step test.
\end{abstract}

Metode Enam puluh dua subyek berusia 18-19 tahun terdiri dari 31 orang berat badan normal dan 31 orang BBL Pemeriksaan tekanan darah dilakukan menggunakan sphygmomanometer pada saat istirahat dan setelah uji Dundee 3 menit. Subjek dinyatakan Hyper-responder bila tekanan darah setelah 3 menit uji Dundee mencapai $180 \mathrm{mmHg}$ atau lebih.

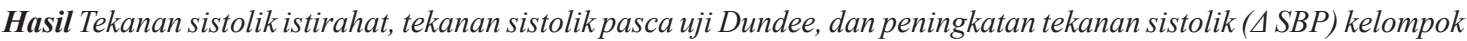
$B B L$ lebih tinggi dibanding kelompok kontrol (116,5 vs 112,8; 163,8 vs 142,7; dan 47,3 vs 29,9; P<0.05). Sebanyak $26 \%$ subyek BBL adalah hyper-responder.

Kesimpulan Terdapat hubungan bermakna antara berat badan lebih dengan tekanan sistolik pasca uji Dundee $(P<0.05)$, yang mengindikasikan adanya gangguan fungsi endotel pada kelompok berat badan lebih dengan tekanan darah normal. (Med J Indones 2010; 19:52-6)

\begin{abstract}
Aim Normotensive overweight adolescents may have endothelial dysfunction which is not clinically detected in a routine clinical examination. The purpose of this study was to detect endothelial dysfunction in normotensive overweight using Dundee step test.

Methods Sixty two subjects consist of 31 normoweight and 31 overweight group participated in this study. Blood pressure measurement was taken at rest and after 3 minutes Dundee step test. Hyper-responder was defined if systolic blood pressure reach $180 \mathrm{mmHg}$ or more after 3 minutes exercise.

Results Mann-Whitney test showed that overweight subjects had significantly higher resting systolic blood pressure, post exercise blood pressure anf magnitude of SBP change ( $\triangle \mathrm{SBP})$ compared to control subjects (116.5 vs $112.8 ; 163.8$ vs 142.7 vs; and 47.3 vs 29.9; $\mathrm{P}<0.05$ ). Twenty six percent of overweight was diagnosed as hyper-responder.

Conclusion There was significant association between overweight and ExSBP indicating endothelial dysfunction in normotensive overweight adolescents. (Med J Indones 2010; 19:52-6)
\end{abstract}

Key words: adolescent, Dundee step test, endothelial dysfunction, overweight, systolic blood pressure,

The prevalence of overweight and obesity in children and adolescent increases worldwide. Overweight and obesity can cause children and adolescent being affected by diseases that are usually found in adults. ${ }^{1}$ Hypertension is one of those diseases that used to be very rare but has been affecting many more children and adolescent recently. ${ }^{2,3}$ Freedman et al., reported overweight children and adolescent were four and half times more likely to have hypertension. ${ }^{4}$ Sorof et al., also reported prevalence of hypertension in obese children and adolescent was three times higher than in normoweight. ${ }^{5}$

Vascular endothelial dysfunction is one of the mechanisms of hypertension in obesity. ${ }^{6-9}$ Normally, endotheCorrespondence e-mail to: nawanto2005@yahoo.com lial cells produce nitric oxide (NO), which is released continuously by mechanical stimuli of the bloodstream, and on demand by the effect of endogen substance such as acetylcholine and bradykinin., ${ }^{911}$ Nitric oxide is a potent vasodilator because it relaxes smooth muscle in the vascular wall., ${ }^{911,12}$ Endothelial dysfunction reduces NO production that could yield hypertrophy of smooth muscle of the vessel wall, incremental of peripheral resistance which in turn can rise blood pressure..$^{8-11}$

In fact, some people with endothelial dysfunction do not show to have hypertension at routine clinical examination. Assessing endothelial function therefore is important to 
detect endothelial dysfunction promptly. There are some previous methods to assess endothelial function such as angiography, catheterization, vascular tonometry, and ultrasound. ${ }^{6,12}$ However, these methods are usually invasive, expensive, or highly operator-dependent. ${ }^{6}$ Lim et al, from University of Dundee, United Kingdom, has developed a simple method to assess endothelial function using step test, namely Dundee step test. ${ }^{13}$ Exercise systolic blood pressure (ExSBP) response, which partly is a reflection of the endothelial function, could be used to predict whether any risk of future hypertension..$^{10,13,14}$ This study was aimed to examine whether endothelial dysfunction exist in normotensive overweight adolescents.

\section{METHODS}

Sixty 18-19 years old boys participated in this cross sectional study. They were consisted of 31 normotensive overweight and 31 normotensive normoweight. Subjects with obesity, family history of hypertension, or smoking tobacco were excluded.

Height was measured without shoes using microtoisse in Frankfort position at $90^{\circ}$ against wall metal tape $\mathrm{e}^{15}$ to the nearest $0,01 \mathrm{~m}$. Weight was measured using a digital balance with minimal clothes to the nearest 0,1 $\mathrm{kg}$. Body mass index (BMI) was obtained by dividing weight $(\mathrm{kg})$ with height square $(\mathrm{m})^{2}$. Normoweight was defined as BMI at 5th-84th percentiles and overweight was BMI at 85th-94th percentiles according to the BMI-for-age chart from CDC 2000. ${ }^{16}$

\section{Blood Pressure Measurements}

Resting blood pressure was measured three times at one occasion for each subject in sitting position after $5 \mathrm{~min}$ utes rest. The subjects had to refrain from tea, coffee, alcohol, smoking, or exercise at least 30 minutes prior to examination. Exercise blood pressure (ExSBP) was measured just at the end of the third minutes step test while the subjects is still stepping. ${ }^{10,13}$ All blood pressure measurements was taken using a standard sphygmomanometer (Erka, Germany)

\section{Dundee Step Test and Interpretation}

Dundee step test was conducted in a laboratory with temperature and humidity at $20^{\circ} \mathrm{C}$ and $60 \%$ respectively. Subject should refrain from physical activity for at least 30 minutes prior to the test. Step test was performed at a bench of $17.5 \mathrm{~cm}$ height and a stepping rate of 92 per minute, set using a metronome. Step test trial for customization was done prior to the test. On the first tick of metronome subject lifted right foot on the bench followed by the left one on the second tick. On the third tick subject lowered the right foot followed by the left foot on the fourth tick. The work intensity of the test was 5 METs (Metabolic equivalent, 1 METs equal with $3.5 \mathrm{ml} / \mathrm{kg} / \mathrm{min}$ ), adjusted according to the cycleergometer sub-maximal exercise developed by Mundal et al. In normotensive, negative result when ExSBP rise to $<180 \mathrm{mmHg}$ and is defined as hypo-responder. Positive result was if ExSBP rose to $>180 \mathrm{mmHg}$ and was defined as hyper-responder. Elevation of ExSBP to $>$ $180 \mathrm{mmHg}$ had a predictive value for sustained hypertension $(140 / 90 \mathrm{mmHg})$ of $76 \% .^{10,13}$

\section{Statistic Analysis}

Shapiro-Wilk was used to examine normality of the data distribution. Unpaired t-test was applied to compare between two normal distributed variables. Mann Whitney was used as an alternative for unpaired t-test if data were not normally distributed. Association between overweight and ExSBP was analyzed using Fisher's test. Data are presented as mean + SD. Statistical analysis was processed using SPSS version 12,0.

\section{RESULTS}

Among variables, height was the only variable with normal distribution. There were no difference in age, height, and resting diastolic blood pressure between control and overweight.

ExSBP were significantly elevated in both groups. Systolic pressure increased $26.5 \%$ in control group $(95 \% \mathrm{CI}=24.5$ to $35.2, \mathrm{P}=0,00)$ and $40.6 \%$ in overweight $(95 \% \mathrm{CI}=41.7$ to $52.9, \mathrm{P}=0,00)$. ExSBP and Systolic changes $(\triangle \mathrm{SBP})$ in overweight are significantly higher than in control group $(95 \% \mathrm{CI}=9.8$ to 25.0 . $\mathrm{P}=00,95 \% \mathrm{CI}=25.0$ to $9.8, \mathrm{P}=0,00$, respectively). Diastolic changes are very small and not significant in both groups $(1.9 \%$ in control group, $0.2 \%$ in overweight) (Table 2).

Eight overweight subjects $(25.8 \%)$ were diagnosed as hyper-responder whereas in control group there was not hyper-responder. Fisher's test showed association between overweight and hyper-responder $(\mathrm{P}=0.02)$ (Table 3). 
Table 1. Comparison of the anthropometric and blood pressure between groups

\begin{tabular}{lccc}
\hline & Overweight & Control & $\mathrm{P}$ \\
\hline Height $(\mathrm{m})$ & $1.70 \pm 0.06$ & $1.70 \pm 0.06$ & 0.11 \\
Weight $(\mathrm{kg})$ & $85.1 \pm 11$ & $63.9 \pm 7.0$ & 0.00 \\
BMI $\left(\mathrm{kg} / \mathrm{m}^{2}\right)$ & $28.3 \pm 1.4$ & $22.2 \pm 1.8$ & 0.00 \\
Resting SBP $(\mathrm{mmHg})$ & $116.5 \pm 2.7$ & $112.8 \pm 5.3$ & 0.00 \\
Resting DBP $(\mathrm{mmHg})$ & $75.8 \pm 2.5$ & $74.1 \pm 4.3$ & 0.18 \\
\hline
\end{tabular}

Table 2. Systolic and diastolic change after Dundee step test

\begin{tabular}{lccc}
\hline & Overweight & Control & $\mathrm{P}$ \\
\hline ExSBP $(\mathrm{mmHg})$ & $163.8 \pm 14.7$ & $142.7 \pm 14.2$ & 0.00 \\
$\Delta$ SBP $(\mathrm{mmHg})$ & $47.3 \pm 15.3$ & $29.9+14.6$ & 0.00 \\
ExDBP $(\mathrm{mmHg})$ & $76.0 \pm 7.1$ & $75.5 \pm 6.1$ & 0.94 \\
$\Delta$ DBP $(\mathrm{mmHg})$ & $0.13 \pm 7.8$ & $1.4 \pm 5.5$ & 0.53 \\
\hline
\end{tabular}

Table 3. Fisher's test for association between overweight and hyper-responder

\begin{tabular}{lccc}
\hline & $\begin{array}{c}\text { Overweight } \\
(\mathrm{n})\end{array}$ & $\begin{array}{c}\text { Control } \\
(\mathrm{n})\end{array}$ & Fisher's test \\
\hline Hypo-responder & 23 & 31 & \\
Hyper-responder & 8 & - & 0.00 \\
\hline
\end{tabular}

\section{DISCUSSION}

The main purpose of this study was to assess endothelial function in normotensive overweight adolescents using Dundee step test. This study has found that normotensive overweight showed higher elevation ExSBP response to Dundee step test. In addition, some overweight subjects had an exaggerated systolic blood pressure during the test known as hyper-responder. Although there were only $26 \%$ of overweight was diagnosed as hyper-responder, mean increased of SBP were almost 50 $\mathrm{mmHg}$. Eventhough with normal resting blood pressure, such high increased BP after Dundee step test might also indicate endothelial dysfunction which would develop to become hypertension in the future. Based on this result, normotensive overweight adolescents are at higher risk of future sustained hypertension

Limitation of this study was difficulty in measuring blood pressure during stepping using manual sphygmomanometer. With moving body and arm, there was noise that could affect our listening to Korotkoff sound. Measurement must be done several times to confirm the result with a consequence adding test time for seconds. Another limitation were that heart rate and abdominal obesity indicators, which could strengthen our discussion, were not available.

There were no different characteristics of the study groups that might affect resting SBP and ExSBP. Age and height are factors considered to influence resting blood pressure 17 that may also affect ExSBP, are found no difference between groups. Also, moderate intensity of the exercise test and short height of the bench are not considered to give significant difference of the ExSBP.

It is estimated that SBP rise 5 to $10 \mathrm{mmHg}$ for every 1 METs of effort. ${ }^{18}$ With 1 METs is energy expended in the resting state, ExSBP after completion Dundee step test would be expected to rise 20 to $40 \mathrm{mmHg}$. Dundee step test had an intensity of 5 METs, considered at the level of moderate intensity and equal with energy expenditure of most daily living activity. ${ }^{10}$ This such intensity level assures that ExSBP during the test will not exceed normal limit for increased ExSBP.

Increased SBP during exercise is a normal physiologic phenomenon. This is attributed to increased cardiac output which is up to several times during exercise. ${ }^{19}$ In addition, shear stress generated by increased blood flow enhance NO production result in vasodilatation to prevent exaggerated SBP..$^{10}$ Production of NO is impaired in endothelial dysfunction leading to exaggerated SBP. ${ }^{10,13,14}$ In fact, ExSBP reflects not only endothelial dysfunction but also correlate with other cardiovascular complications and hypertension related-organ damage. Fazio et $\mathrm{l}^{20}$ reported prehypertensive with ExSBP showed thicker left ventricular wall, longer left ventricular isovolumic relaxation time, and more number of arterial stiffness. Kurl et $\mathrm{al}^{21}$ found that increase in SBP during exercise were associated with risk of all strokes directly and independently. However, further investigation is still needed to examine predictive effect of ExSBP on hypertension related-organ damage other than cardiovascular system.

Endothelial dysfunction is characterized by imbalance between constriction and dilatation state due to factors affecting vascular physiology. ${ }^{7}$ Endothelial cells produce vasodilator as well as vasoconstrictor substance such as NO and endothelin-1 (ET-1) respectively. ${ }^{7}$ Sympathetic nervous system (SNS) is an external factor which also contributes to the balance state..$^{22,23}$ Thus, 
increased ET-1 secretion and SNS activity will result in vasoconstriction whereas increased NO production and diminished SNS activity will lead to vasodilatation.

NO and ET-1 secretion is regulated by intracellular signaling mediated by insulin through PI3-kinase pathway. ${ }^{24,25}$ The pathway is initialized by binding of insulin to its receptor to form insulin receptor substrate (IRS). IRS formation will initiate reaction which finally activates protein kinase B (Akt). ${ }^{7,24,25}$ Activation of Akt will directly induce endothelial nitric oxide synthase (eNOS) activity leading to NO production by endothelium vascular. ${ }^{911}$ Bioavailability of $\mathrm{NO}$ is diminished in the present of reactive oxygen species (ROS). ${ }^{11,24,25}$ In the other hand, through MAPK pathway, insulin also stimulates ET-1, a vasoconstrictor. ${ }^{7}$

Adipose tissue, mainly in visceral obesity, is not merely passive energy store but is like an endocrine organ producing several biologically active substances. ${ }^{7,9}$ Beside free fatty acid (FFA) resulted from lipolytic, adipose tissue in visceral obesity secretes inflammatory cytokines such as tumor necrosis factor (TNF)- $\alpha$, adipokines such as leptin and adiponektin. ${ }^{7,22,23}$ Adipose tissue is also a source of angiotensinogen (AGN), an inactive form which is then transformed into an active form function as vasoconstrictor, angiotensin II (Ang II). These substances, Ang II, TNF- $\alpha$, and FFA, reduce NO production by suppressing PI3-kinase, increasing ROS production and ET-1.9,22-25 TNF- $\alpha$ also suppresses eNOS activity. ${ }^{7,9}$

Leptin, an adiponectin secreted by adipose tissue, also plays role in hypertension. ${ }^{911}$ With increasing body fat as in overweight and obesity, leptin production is also increased to suppress appetite in turn reducing food intake and bodyweight. ${ }^{22,23}$ In relation to hypertension, leptin elevates SNS activity through a melanocortindependent pathway within hypothalamus. ${ }^{7,22}$ Elevation of the SNS system activity leads to vasoconstriction, increased peripheral resistance, and increased blood pressure. In contrast to leptin, adiponectin that reduces with increasing body fatness improves the insulin signaling-cascade leading to vasodilatation. ${ }^{7,24,25}$ Elevated resting blood pressure in overweight may be an indication of increased SNS activity in this study.

In conclusion, the recent study has found that hyper-responder that reflects endothelial dysfunction is detected in some overweight adolescents with normal blood pressure using Dundee step test. Endothelial dysfunction in overweight adolescents may also manifest as higher resting systolic pressure and mean increases of ExSBP above $40 \mathrm{mmHg}$. We suggest for further study to examine endothelial dysfunction in children and to make threshold ExSBP indicating endothelial dysfunction. We also recommend performing further examination to find endothelial dysfunction in subjects diagnosed as hyporesponder with increased ExSBP above $40 \mathrm{mmHg}$.

\section{Acknowledgment}

Authors would like to thanks Atmajaya medical students for participation

\section{REFERENCES}

1. Sorof J, Daniels S. Obesity hypertension in children. A problem of epidemic proportions. Hypert 2002;40:441-7

2. Salvadori M, Sontrop JM, Garg AX, Truong J, Suri RS, Mahmud FH, et al. Elevated blood pressure in relation to overweight and obesity among children in a rural Canadian community. Pediatr 2008;122:e821-7

3. Daniels SR, Jacobson MS, McCrindle BW, Eckel RH, Sanner BM. American Heart Association childhood obesity research summit. Executive summary. Circulation 2009;119:2114-23

4. Freedman DS, Dietz WH, Srinivasan SR, Berenson GS. The relation of overweight to cardiovascular risk factors among children and adolescents: the Bogalusa heart study. Pediatr 1999; 103:1175-82

5. Sorof JM, Poffenbarger T, Franco K, Bernard L, Portman RJ. Isolated systolic hypertension, obesity, and hyperkinetic hemodynamic states in children. J Pediatr 2002;140:660-6

6. Widlansky ME, Gokce N, Keaney JF, Vita JA. The clinical implications of endothelial dysfunction. J Am Coll Cardiol 2003;42:1149-60

7. Jonk AM, Houben AJHM, de Jongh RT, Serné EH, Schaper NC, Stehouwer CDA. Microvascular dysfunction in obesity: a potential mechanism in the pathogenesis of obesity-associated insulin resistance and hypertension. Physiol 2007;22(4):252-60

8. Goligorsky MS. Endothelial cell dysfunction: can't live with it, how to live without it. Am J Physiol Renal Physiol 2005;288:F871-80

9. Félétou M, Vanhoutte PM. Endothelial dysfunction: a multifacet disorder. Am J Physiol Heart Circ Physiol 2006;291:H985-1002

10. Tzemos N, Patterson D, MacDonald TM. Dundee step test: a novel non-invasive method of assessing endothelial function in man. South Med J 2002;47(1):3-6

11. Potenza MA, Addabbo F, Monica Montagnani M. Vascular actions of insulin with implications for endothelial dysfunction. Am J Physiol Endocrinol Metab 2009;297: E568-77.

12. Singhal A. Endothelial dysfunction: role in obesity-related disorders and the early origins of CVD. Proc Nutr Soc 2005;64(1):15-22 
13. Lim PO, Shiels P, Anderson J, MacDonald TM. Dundee step test: a simple method of measuring the blood pressure response to exercise. J Hum Hypert 1999;13(8):521-6

14. Tzemos N, Lim PO, MacDonald TM. Exercise blood pressure and endothelial dysfunction in hypertension. Int J Clin Pract 2009;63(2):202-6

15. Norton K, Olds T, editors. Anthropometrica. A textbook of body measurement for sports and health courses. 1st ed. Sydney: UNSW Press; 1996

16. www.cdc.gov/nchs/data/nhanes/growthcharts/2000

17. The National High Blood Pressure Education Program (NHBEP) Working Group on High Blood Pressure in Children and adolescents. The fourth report on the diagnosis, evaluation, and treatment of high blood pressure in children and adolescents. Pediatr 2004;114:555-76

18. Taylor AJ, Beller GA. Postexercise systolic blood pressure response: clinical application to the assessment of ischemic heart disease. Am Fam Physic 1998;58:1126-32

19. McArdle WD, Kath FI, Katch VL. Essential of exercise physiology. 3rd ed. Baltimore:Lippincott Williams \& Wilkins;2006
20. Fazio S, Palmieri EA, Izzo R, Affuso F, Romano M, Riccio $\mathrm{G}$, et al. An exaggerated systolic blood pressure response to exercise is associated with cardiovascular remodeling in subjects with prehypertension. Ital Heart J 2005;6:886-92

21. Kurl S, Laukkanen JA, Rauramaa R, Lakka TA, Sivenius J, Salonen JT. Systolic blood pressure response to exercise stress test and risk of stroke. Stroke 2001;32:2036-41

22. Rahmouni K, Correia MLG, Haynes WG, Mark AL. Obesity-associated hypertension. New insight into mechanisms. Hypert 2005;45:9-14

23. Mathieu P, Poirier P, Pibarot P, Lemieux I, Després JP. Visceral obesity. The link among inflammation, hypertension, and cardiovascular disease. Hypert 2009;53:577-84

24. Mark T, Kearney MT, Duncan ER, Kahn M, Wheatcroft SB. Insulin resistance and endothelial cell dysfunction: studies in mammalian models 2008 Exp Physiol;93:158-63.

25. Wang CCL, Goalstone ML, Draznin B. Molecular Mechanisms of Insulin Resistance That Impact Cardiovascular Biology. Diabetes 2004;53(11):2735-40 